\title{
Protective Effects of Oral Disodium Cromoglycate on the Asthmatic Responses Induced by Food Allergy
}

\section{Zdenek Pelikan*}

Allergy Research Foundation, The Netherlands

\begin{abstract}
Background: The food allergy can also participate in the pathological mechanism underlying the bronchial asthma. This should ultimately be confirmed by food ingestion challenge combined with monitoring of lung function ( $F V C$ and $\mathrm{FEV}_{1}$ ), demonstrating the particular types of asthmatic response to ingested foods. The oral disodium cromoglygate (DSCG, Nalcrom ${ }^{\circledR}$ ) has been shown to be effective drug in prevention of food allergy.

Methods: In 62 randomly selected patients with bronchial asthma developing 62 asthmatic responses to food ingestion challenge (17 immediate, IAR, $\mathrm{p}<0.01 ; 21$ late, LAR, $\mathrm{p}<0.001 ; 8$ dual late, DLAR, $\mathrm{p}<0.05 ; 11$ delayed DYAR, $p<0.05$; and 5 dual delayed DDYAR, $p<0.05$ ), the food ingestion challenges have been repeated twice, after the pretreatment with oral DSCG and after pretreatment with oral placebo. The study was performed according the double-blind, placebo-matched, cross-over design.

Results: The DSCG, administered orally in a daily dose of $4 \times 200 \mathrm{mg}$ starting 2 weeks before and continuing through the challenge day up to 3 days after the challenge, as compared with placebo, protected highly significantly the IAR $(p<0.001)$, and the LAR $(p<0.001)$, protected distinctly significantly the DLAR $(p<0.01)$ and significantly the DYAR $(p<0.05)$ and DDYAR $(p<0.05)$. However, the distribution of the protective effects of oral DSCG on the particular types of asthmatic response to ingested foods has varied. The oral placebo was fully ineffective $(p>0.2)$. No differences in the DSCG protective effects were observed with respect to the individual foods $(p>0.2)$.

Conclusions: It can be concluded that the food allergy can causally be involved in some patients with bronchial asthma, resulting in development of various types of asthmatic response. The asthmatic responses to food ingested can effectively be prevented by pretreatment with disodium cromoglycate administered orally in a daily dose of $4 x$ $200 \mathrm{mg}$. If necessary the treatment with oral DSCG can be combined with other treatments, such as elimination diet and/or other additional drugs, e.g. $\beta_{2}$-sympathomimetics or other drugs.
\end{abstract}

Keywords: Bronchial asthma; Food allergy; Food ingestion challenge; Types of asthmatic response to food ingested; Oral disodium cromoglycate

Abbreviations: DSCG: Disodium Cromoglycate; BPT: Bronchial Provocation Test; SPT: Skin Prick Test; BU: Biologic Unit; FVC: Forced

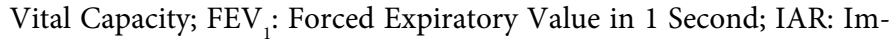
mediate (Early) Asthmatic Response; LAR: Late Asthmatic Response; DLAR: Dual Late Asthmatic Response (a combination of IAR and LAR); DYAR: Delayed Asthmatic Response; DDYAR: Dual Delayed Asthmatic Response (a combination of IAT and DYAR)

\section{Introduction}

Food allergy is a multifactorial clinical manifestation of an immunological process in which foods, their parts and/or components act as antigens, stimulating the production of specific antibodies against them self or sensitizing the particular T-lymphocyte subset(s) and subsequently interacting with them [1-18]. Food allergy was classically attributed to the immediate (IgE-mediated) hypersensitivity mechanism(s) [1-5,8-12]. Nevertheless, later evidence has been found for the possible involvement of also other, so-called non-IgE-mediated, hypersensitivity mechanism types, such as late (immune-complex-mediated) and delayed (cell-mediated) types of hypersensitivity in food allergy [7-10,12-17,19-37]. Food allergy can be involved in various disorders of the respiratory tract, such as bronchial asthma, allergic rhinitis, sinusopathy, etc [1-3,6-10,1217,19-21,23-25,38-42]. This involvement can occur either in a primary form, where the foods act as the sole causal factor in this disorder, or in a more frequently occurring secondary form, wherein addition to the already existing bronchial asthma to inhalant allergens, the foods play an additional role $[6,7,19,23-25,43]$. The involvement of food allergy in patients with bronchial asthma leads to the development of various types of asthmatic response, such as immediate/early (IAR/ EAR), late (LAR), dual late (DLAR, a combination of an immediate and a late response),delayed (DYAR) and dual delayed (DDYAR, a combination of an immediate and a delayed) responses, described in our previous papers and reported also by other investigators [7,8,12-14,16,17,19-21,23-25,27-35,37,38,44-46]. The particular types of asthmatic response to food ingestion challenge differ each from other with respect to their clinical features, the association with other diagnostic parameters and the possibly underlying immunologic mechanisms [7,9-15,19-35,38,47-54]. The provocation tests with foods should be considered to be definite confirmation of the involvement of the certain foods in the patient's complaints, e.g. bronchial asthma [1-12,14-16,19-21,23-25,30,31,37-40,41,44-64]. Unfortunately the role of food allergy in patients with bronchial asthma is still underestimated by the clinicians because: (a) there is a the dearth of information

*Corresponding author: Dr. Z. Pelikan, Allergy Research Foundation, Effenseweg 42, 4838 BB Breda, The Netherlands, Tel: 31-76-522 30 74; Fax: 31-76-52 00607 E-mail: zpelikan@casema.nl

Received December 26, 2013; Accepted January 27, 2014; Published January 31, 2014

Citation: Pelikan Z (2014) Protective Effects of Oral Disodium Cromoglycate on the Asthmatic Responses Induced by Food Allergy. J Allergy Ther 5: 163. doi:10.4172/2155-6121.1000163

Copyright: (c) 2014 Pelikan Z. This is an open-access article distributed under the terms of the Creative Commons Attribution License, which permits unrestricted use, distribution, and reproduction in any medium, provided the original author and source are credited. 
concerning this problem; (b) the involvement of food allergy in patients with allergic disorders is complex, has various forms and modifications; (c) the diagnostic procedure(s) and confirmation of the in allergy in the patient's complaints is not an easy process, it requires specific conditions and precautions and is not performed in all clinics [1-12,14-16,19-21,23-25,30,31,37-40,41,44-64]. The management of the bronchial asthma due to the food allergy is usually limited to the elimination diet, symptomatic treatment with the H1-sometimes also $\mathrm{H} 2$-receptor antagonists, anticholinergics, beta-2-sympathomimetics and sometimes inhalant corticosteroids.

Disodium cromoglycate (DSCG) administered orally and its possible protective effects on various clinical manifestations and forms of food hypersensitivity have already been discussed in the literature, through sometimes from controversial points of view $[2,5,7,8,15,24,41$ $43,65-75]$. Nevertheless, we were unable to find any report in the literature available concerning the investigation of protective effects of disodium cromoglycate on the particular asthmatic response types due to the food allergy in a sufficiently large, representative and welldiagnosed group of asthmatics. The purpose of this study, being a continuation of our previous preliminary work, was to investigate the possible existence of significant protective effects of disodium cromoglycate. $\left(\mathrm{Nalcrom}^{\circledR}\right)$ on the basic types of asthmatic response to food ingestion challenge in patients with bronchial asthma, and to define the indications for the practical use of this drug in patients suffering from bronchial complaints due to the food ingested/food allergy.

\section{Materials and Methods}

\section{Patients}

Sixty-two patients with bronchial asthma in whom the food allergy was suspected to play a role, who had been referred to our Department of Allergology and Immunology (Institute of Medical Sciences "De Klokkenberg", Breda, The Netherlands) during 1999-2000 for more extensive diagnostic analysis, and developing asthmatic response to ingestion challenge with certain foods, have volunteered to participate in this study.

These patients 18-52 years of age, included 47 subjects with already existing bronchial asthma to inhalant allergens, in whom the suspected food allergy participated additionally in their bronchial complaints (Group I) and 15 subjects in whom the food allergy was suspected to be the sole cause of their bronchial complaints (Group II) (Table 1).

These patients reported suspect/positive history for one or more foods $(81 \%)$, positive skin (prick and/or intracutaneous) tests with various food extracts $(88 \%)$ and some of them also showed positive specific IgE antibody for some foods (Tables 1-4). They had no history of anaphylactic reactions did not suffer from any airway infections or any systemic or serious disorder, did not use oral corticosteroids or immunotherapy and the pregnancy has been excluded. They all demonstrated negative lactose intolerance test. The patients were examined by means of routine diagnostic procedure, serving also as an exclusion- inclusion check i.e. confirmation of a patient 's eligibility for the study and the exclusion of contraindications $[4,6-8,10,11,19,20,23$ $25,39,41,45,47-49,51-58,60,61,63,64]$.

This procedure consisted of: (1) the general part: disease history, physical examination, basic laboratory tests, $\mathrm{X}$-ray of chest and sinuses, lung function, determination of blood gases and bacteriological examination of the sputum; (2) the allergologic part: skin tests with inhalant and food allergens, bronchial histamine threshold [61,75-79], and determination of the serum immunoglobulins; (3) 109 bronchial challenges with inhalant allergens (BPT) [75-79] and (4) 97 ingestion challenges with selected foods, suspected from the history and/or skin tests, in combination with recording of the lung function (FVC and $\mathrm{FEV}_{1}$ ). A 7-day interval was always inserted between the consecutive tests, to prevent carry-over effects. All challenges were performed during a period without manifest symptoms and during a short hospitalization of the patient under standard conditions. The particular food used for the challenges has always been avoided for 4 weeks before the challenges.

Inhaled glucocorticosteroids $(\mathrm{n}=27)$ and long-acting $\beta_{2}$ symphatomimetics $(n=55)$ were withdrawn 4 weeks, inhaled cromolyn $(\mathrm{n}=19)$, inhaled nedocromil $(\mathrm{n}=11)$ and leukotriene modifiers $(\mathrm{n}=4) 2$ weeks and other treatments 48 hours before each of the challenges. If the FEV ${ }_{1}$ or both the FVC and $\mathrm{FEV}_{1}$ values decreased after the allergen challenge and/or food ingestion challenge by $50 \%$ or more, with respect

\begin{tabular}{|c|c|c|c|c|c|c|c|c|}
\hline & \multicolumn{7}{|c|}{ Patients } & \multirow[b]{2}{*}{$\begin{array}{l}\text { Control subjects } \\
n=15\end{array}$} \\
\hline & $\begin{array}{l}\text { Total } \\
n=16\end{array}$ & $\begin{array}{l}\text { IAR } \\
\mathrm{n}=17\end{array}$ & $\begin{array}{l}\text { LAR } \\
n=21\end{array}$ & $\begin{array}{l}\text { DLAR } \\
n=8\end{array}$ & $\begin{array}{l}\text { DYAR } \\
n=11\end{array}$ & $\begin{array}{l}\text { DDYAR } \\
n=5\end{array}$ & $\begin{array}{l}\text { NAR } \\
n=35\end{array}$ & \\
\hline Group I/II & $47 / 15$ & $14 / 3$ & $13 / 8$ & $5 / 3$ & $8 / 3$ & $3 / 2$ & $19 / 16$ & \\
\hline Age (years) & $29 \pm 5$ & $24 \pm 3$ & $30 \pm 4$ & $35 \pm 6$ & $26 \pm 4$ & $25 \pm 2$ & $28 \pm 7$ & $31 \pm 4$ \\
\hline Gender (M/F) & $29 / 33$ & $8 / 9$ & $9 / 12$ & $4 / 4$ & $6 / 5$ & $2 / 3$ & $16 / 10$ & $7 / 8$ \\
\hline Disease history (years) & $5.1 \pm 0.6$ & $5.0 \pm 1.0$ & $4.7 \pm 1.0$ & $5.5 \pm 1.4$ & $5.6 \pm 0.9$ & $4.8 \pm 0.7$ & $5.9 \pm 1.8$ & $4.5 \pm 1.2$ \\
\hline FEV1 (\% predicted) & $96 \pm 5$ & $94 \pm 3$ & $98 \pm 2$ & $95 \pm 6$ & $97 \pm 3$ & $93 \pm 6$ & $95 \pm 3$ & $97 \pm 2$ \\
\hline FVC (\% predicted) & $99 \pm 2$ & $98 \pm 4$ & $100 \pm 3$ & $98 \pm 5$ & $103 \pm 4$ & $99 \pm 3$ & $104 \pm 2$ & $98 \pm 3$ \\
\hline Blood leukocyte count $\left(\times 10^{9} / \mathrm{L}\right) \bullet$ & $8.0 \pm 0.78$ & $8.3 \pm 1.0$ & $7.8 \pm 0.5$ & $6.9 \pm 1.0$ & $9.1 \pm 0.5$ & $9.1 \pm 0.5$ & $8.1 \pm 1.3$ & $7.9 \pm 0.6$ \\
\hline Blood eosinophil count $\left(\times 10^{6} / \mathrm{L}\right) \bullet \bullet$ & $355 \pm 52$ & $389 \pm 44$ & $334 \pm 27$ & $392 \pm 53$ & $257 \pm 19$ & $288 \pm 22$ & $263 \pm 13$ & $413 \pm 69$ \\
\hline Blood neutrophil count $\left(\times 10^{9} / \mathrm{L}\right) \bullet \bullet \bullet$ & $5.4 \pm 0.6$ & $4.9 \pm 0.8$ & $5.6 \pm 0.4$ & $4.8 \pm 1.1$ & $5.1 \pm 1.0$ & $6.9 \pm 0.5$ & $5.5 \pm 0.7$ & $5.3 \pm 0.8$ \\
\hline \multicolumn{9}{|l|}{ Bronchial histamine threshold $(\mathrm{BHT}) \square$} \\
\hline$\leq 2.0 \mathrm{mg} / \mathrm{mL}$ & 4 & 2 & 1 & 0 & 1 & 0 & 8 & 2 \\
\hline $4.0 \mathrm{mg} / \mathrm{mL}$ & 7 & 1 & 2 & 1 & 1 & 2 & 10 & 6 \\
\hline $8.0 \mathrm{mg} / \mathrm{mL}$ & 6 & 2 & 1 & 2 & 0 & 1 & 9 & 5 \\
\hline $16.0 \mathrm{mg} / \mathrm{ml}$ & 9 & 3 & 2 & 2 & 1 & 1 & 6 & 1 \\
\hline $32.0 \mathrm{mg} / \mathrm{ml}$ & 14 & 3 & 3 & 3 & 4 & 1 & 2 & 1 \\
\hline$>32.0 \mathrm{mg} / \mathrm{mL}$ & 22 & 6 & 12 & 0 & 4 & 0 & 0 & 0 \\
\hline
\end{tabular}

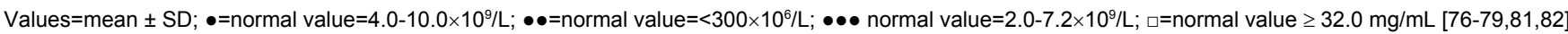
Table 1: Clinical characteristics of the patients and control subjects. 
Citation: Pelikan Z (2014) Protective Effects of Oral Disodium Cromoglycate on the Asthmatic Responses Induced by Food Allergy. J Allergy Ther 5: 163. doi: $10.4172 / 2155-6121.1000163$

Page 3 of 11

\begin{tabular}{|c|c|c|c|c|c|c|c|c|}
\hline Foods & $\begin{array}{l}\text { Total } \\
n=16\end{array}$ & $\begin{array}{l}\text { Amount } \\
\text { ingested }\end{array}$ & $\begin{array}{l}\text { IAR } \\
\mathrm{n}=17\end{array}$ & $\begin{array}{l}\text { LAR } \\
n=21\end{array}$ & $\begin{array}{l}\text { DLAR } \\
n=8\end{array}$ & $\begin{array}{l}\text { DYAR } \\
n=11\end{array}$ & $\begin{array}{l}\text { DDYAR } \\
n=5\end{array}$ & $\begin{array}{l}\text { NAR } \\
n=35\end{array}$ \\
\hline Milk & 10 & $100 \mathrm{~mL}$ & 3 & 3 & 1 & 2 & 1 & 4 \\
\hline Cheese & 7 & $100 \mathrm{~g}$ & 2 & 2 & 0 & 2 & 1 & 3 \\
\hline Chocolade & 6 & $50 \mathrm{~g}$ & 2 & 2 & 1 & 1 & 0 & 3 \\
\hline Peanuts & 4 & $20 \mathrm{~g}$ & 1 & 1 & 0 & 1 & 1 & 1 \\
\hline Almonds & 2 & $20 \mathrm{~g}$ & 0 & 1 & 0 & 1 & 0 & 4 \\
\hline Hazelnuts & 3 & $20 \mathrm{~g}$ & 1 & 1 & 0 & 1 & 0 & 3 \\
\hline Cashews & 1 & $20 \mathrm{~g}$ & 0 & 0 & 0 & 1 & 1 & 2 \\
\hline Walnuts & 1 & $20 \mathrm{~g}$ & 0 & 1 & 0 & 0 & 0 & 0 \\
\hline Shrimps & 6 & $50 \mathrm{~g}$ & 2 & 2 & 1 & 0 & 1 & 1 \\
\hline Haring & 1 & $100 \mathrm{~g}$ & 0 & 1 & 0 & 0 & 0 & 1 \\
\hline Eggs & 2 & $30 \mathrm{~g}$ & 0 & 0 & 1 & 1 & 0 & 2 \\
\hline Tomato & 3 & $100 \mathrm{~g}$ & 1 & 1 & 1 & 0 & 0 & 2 \\
\hline Lettuce & 1 & $100 \mathrm{~g}$ & 0 & 1 & 0 & 0 & 0 & 1 \\
\hline Onion & 3 & $10 \mathrm{~g}$ & 2 & 1 & 0 & 0 & 0 & 2 \\
\hline Garlic & 2 & $5 \mathrm{~g}$ & 0 & 1 & 1 & 0 & 0 & 1 \\
\hline Horseradish & 1 & $50 \mathrm{~g}$ & & & & & & 0 \\
\hline Banana & 2 & $100 \mathrm{~g}$ & 1 & 0 & 1 & 0 & 0 & 1 \\
\hline Apple & 3 & $100 \mathrm{~g}$ & 1 & 1 & 0 & 1 & 0 & 2 \\
\hline Peer & 1 & $100 \mathrm{~g}$ & 0 & 1 & 0 & 0 & 0 & 0 \\
\hline Pork & 2 & $50 \mathrm{~g}$ & 1 & 1 & 0 & 0 & 0 & 0 \\
\hline Lamb & 1 & $50 \mathrm{~g}$ & 0 & 0 & 1 & 0 & 0 & 1 \\
\hline Sherry & 1 & $20 \mathrm{~mL}$ & 0 & 1 & 0 & 0 & 0 & 1 \\
\hline
\end{tabular}

Table 2: Foods caused particular types of asthmatic response.

\begin{tabular}{|c|c|c|c|c|c|c|c|c|}
\hline & \multicolumn{7}{|c|}{ Patients } & \multirow[b]{2}{*}{$\begin{array}{l}\text { Control } \\
\text { subjects } n=15\end{array}$} \\
\hline & $\begin{array}{l}\text { Total } \\
n=62\end{array}$ & $\begin{array}{l}\text { IAR } \\
n=17\end{array}$ & $\begin{array}{l}\text { LAR } \\
n=21\end{array}$ & $\begin{array}{l}\text { DLAR } \\
n=8\end{array}$ & $\begin{array}{l}\text { DYAR } \\
n=11\end{array}$ & $\begin{array}{l}\text { DDYAR } \\
n=5\end{array}$ & $\begin{array}{l}\text { NAR } \\
n=35\end{array}$ & \\
\hline \multicolumn{9}{|l|}{ Positive SPT response $\diamond$} \\
\hline - immediate & 15 & 8 & 3 & 4 & 0 & 0 & 9 & 0 \\
\hline Negative SPT response $\diamond$ & 47 & 9 & 18 & 4 & 11 & 5 & 26 & 15 \\
\hline Positive i.c.test response $\diamond \diamond$ & 55 & 15 & 18 & 7 & 10 & 5 & 34 & 14 \\
\hline - immediate & 23 & 11 & 6 & 3 & 2 & 1 & 6 & 5 \\
\hline - late & 22 & 4 & 12 & 4 & 1 & 1 & 23 & 9 \\
\hline - delayed & 10 & 0 & 0 & 0 & 7 & 3 & 5 & 0 \\
\hline Negative i.c. test response $\diamond \diamond$ & 7 & 2 & 3 & 1 & 1 & 0 & 1 & 1 \\
\hline Increased total IgE (serum) & 4 & 2 & 2 & 0 & 0 & 0 & 3 & 0 \\
\hline Positive specific lgE (serum) & 9 & 5 & 3 & 1 & 0 & 0 & 1 & 1 \\
\hline Increased total IgG (serum)• & 5 & 2 & 2 & 1 & 0 & 0 & 1 & 0 \\
\hline \multicolumn{9}{|l|}{ Increased sub-classes (serum)•• } \\
\hline$-\lg G 1$ & 1 & 0 & 1 & 0 & 0 & 0 & 0 & 0 \\
\hline$-\lg G 2$ & 0 & 0 & 0 & 0 & 0 & 0 & 0 & 0 \\
\hline$-\lg G 3$ & 2 & 1 & 1 & 0 & 0 & 0 & 0 & 0 \\
\hline$-\lg G 4$ & 2 & 1 & 0 & 1 & 0 & 0 & 0 & 0 \\
\hline Increased total IgM (serum)••• & 0 & 0 & 0 & 0 & 0 & 0 & 0 & 0 \\
\hline Increased total IgA (serum) & 3 & 1 & 1 & 2 & 0 & 0 & 0 & 0 \\
\hline \multicolumn{9}{|l|}{ Concomitant disorders } \\
\hline - allergic rhinitis & 9 & 3 & 3 & 2 & 1 & 0 & 1 & 1 \\
\hline - atopic eczema & 17 & 5 & 8 & 2 & 1 & 1 & 0 & 2 \\
\hline - urticaria & 3 & 0 & 1 & 2 & 0 & 0 & 0 & 0 \\
\hline - angio-neurotic edema & 1 & 0 & 0 & 1 & 0 & 0 & 0 & 0 \\
\hline - gastrointestinal complaints & 21 & 9 & 10 & 1 & 1 & 0 & 0 & 0 \\
\hline
\end{tabular}

IAR:Immediate Asthmatic Response; LAR: Late Asthmatic Response; DLAR: Dual Late Asthmatic Response (immediate+late); DYAR: Delayed Asthmatic Response; DDYAR: Dual Delayed Asthmatic Response (immediate+delayed); NAR=NegativeAsthmatic Response; $\diamond=S k i n$ Prick Test (SPT); $\diamond \diamond=i n t r a c u t a n e o u s$ (intradermal) skin

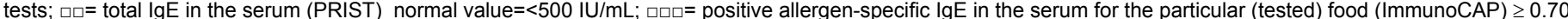
$\mathrm{U} / \mathrm{mL}$ (=more than class 1 ); $\bullet=$ total $\mathrm{lgG}$ in the serum (Single radial immunodiffusion and ELISA)-normal value $\leq 15.0 \mathrm{~g} / \mathrm{L} ; \bullet \bullet=$ normal values: IgG1<5.0 g/L, IgG2<2.6 g/L, $\operatorname{lgG} 3<0.4 \mathrm{~g} / \mathrm{L}, \operatorname{lgG} 4<0.5 \mathrm{~g} / \mathrm{L} ; \bullet \bullet \bullet=\operatorname{lgM} \leq 3.8 \mathrm{~g} / \mathrm{L} ; \boldsymbol{m = \operatorname { l g A }} \leq 4.0 \mathrm{~g} / \mathrm{L}$;

Table 3: Survey of other diagnostic parameters.

to the predicted values, the patients $(n=3)$ were treated with a single dose of $400 \mu \mathrm{g}$ salbutamol aerosol. The local ethical committee (IRBMCK) approved the study and informed consent was obtained from all study participants. The study was conducted according to the WMA Declaration of Helsinki concerning the principles for medical research involving human subjects. 


\begin{tabular}{|l|l|l|l|l|}
\hline & $\begin{array}{l}\text { History + } \\
\text { Skin }+\end{array}$ & $\begin{array}{l}\text { History } \pm \\
\text { Skin }+\end{array}$ & $\begin{array}{l}\text { History + } \\
\text { Skin - }\end{array}$ & Total \\
\hline $\begin{array}{l}-62 \text { positive } \\
\text { responses }\end{array}$ & $46(74 \%)$ & $9(15 \%)$ & $7(11 \%)$ & $62(100 \%)$ \\
\hline $\begin{array}{l}-35 \text { negative } \\
\text { responses }\end{array}$ & $6(17 \%)$ & $21(60 \%)$ & $8(23 \%)$ & $35(100 \%)$ \\
\hline Total & $54(55 \%)$ & $30(30 \%)$ & $15(15 \%)$ & $97(100 \%)$ \\
\hline
\end{tabular}

$+=$ positive; \pm =unknown; - =negative

Table 4: Agreement between disease history and skin tests.

\begin{tabular}{|c|c|c|c|c|c|c|c|}
\hline \multirow[b]{2}{*}{$\begin{array}{l}\text { Bronchial } \\
\text { Complaints }\end{array}$} & \multicolumn{6}{|c|}{ Patients } & \multirow[b]{2}{*}{$\begin{array}{l}\text { Control } \\
\text { subjects } \\
n=15\end{array}$} \\
\hline & $\begin{array}{l}\text { IAR } \\
n=17\end{array}$ & $\begin{array}{l}\text { LAR } \\
n=21\end{array}$ & $\begin{array}{l}\text { DLAR } \\
n=8\end{array}$ & $\begin{array}{l}\text { DYAR } \\
n=11\end{array}$ & $\begin{array}{l}\text { DDYAR } \\
n=5\end{array}$ & $\begin{array}{l}\text { NAR } \\
n=35\end{array}$ & \\
\hline \multicolumn{8}{|l|}{ Dyspnea } \\
\hline -- & 0 & 0 & 0 & 0 & 0 & 97 & 100 \\
\hline+ & 12 & 5 & 12 & 0 & 20 & 3 & 0 \\
\hline++ & 53 & 71 & 38 & 73 & 40 & 0 & 0 \\
\hline+++ & 35 & 24 & 50 & 27 & 40 & 0 & 0 \\
\hline \multicolumn{8}{|l|}{ Wheezing } \\
\hline -- & 0 & 0 & 0 & 0 & 0 & 94 & 93 \\
\hline+ & 0 & 10 & 38 & 0 & 40 & 3 & 7 \\
\hline++ & 47 & 43 & 12 & 45 & 40 & 3 & 0 \\
\hline+++ & 53 & 47 & 50 & 55 & 20 & 0 & 0 \\
\hline \multicolumn{8}{|l|}{ Cough } \\
\hline-- & 6 & 4 & 63 & 9 & 40 & 100 & 100 \\
\hline+ & 6 & 29 & 13 & 0 & 20 & 0 & 0 \\
\hline++ & 41 & 29 & 24 & 27 & 40 & 0 & 0 \\
\hline+++ & 47 & 38 & 0 & 64 & 0 & 0 & \\
\hline \multicolumn{8}{|l|}{ Expectoration } \\
\hline-- & 83 & 76 & 100 & 9 & 100 & 100 & 100 \\
\hline+ & 17 & 24 & 0 & 91 & 0 & 0 & 0 \\
\hline
\end{tabular}

Bronchial complaints (author's modified score system): --=absent , +=slight $++=$ moderate/intermittent, +++=pronounced /regularly

Table 5: Survey of bronchial complaints during the asthmatic response types to food ingestion (in \%).

\section{Allergens}

Dialyzed and lyophilized allergen extracts of inhalant allergens as well as of foods (Allergopharma, Reinbek, Germany) diluted In PBS (phosphate-buffered saline) were used in concentrations of 50-500 $\mathrm{BU} / \mathrm{mL}$ for skin tests and in concentrations of $1000-3000 \mathrm{BU} / \mathrm{mL}$ for bronchial challenges (BPTs). The concentrations recommended by the manufacturer were $100-500 \mathrm{BU} / \mathrm{mL}$ for skin prick as well as intradermal tests (SPTs) and $5000 \mathrm{BU} / \mathrm{mL}$ for the BPTs.

\section{Skin tests}

The skin prick tests (SPTs) in concentration of $500 \mathrm{BU} / \mathrm{mL}$ were performed and evaluated after 20 minutes and again after 24 hours. If the SPT were negative, than intracutaneous (intradermal) tests in concentrations of $100 \mathrm{BU} / \mathrm{mL}$ and $500 \mathrm{BU} / \mathrm{mL}$ were carried out and evaluated 20 minutes, $6,12,24,36,48,72$ and 96 hours after the injection $[6,7,19,20,23-25,40,43,61,76-80]$. If the SPTs were positive (early/immediate skin response), then the intracutaneous tests were performed in concentrations of $200 \mathrm{BU} / \mathrm{mL}$ and evaluated up to 96 hours after the injection. Histamine diphosphate was used as a positive, whereas PBS as a negative control. A skin wheal (>7.0 $\mathrm{mm}$ in diameter) appearing within 20 minutes after the injection was considered to be a positive immediate skin response, the skin infiltration observed between 6-12 hours to be a late skin response and the skin in duration than recorded 48 hours orlater to was designated a delayed skin response $[6,7,19,20,23-25,40,43,61,76-80]$.

\section{Spirometry}

The asthmatic responses were monitored by means of spirometry (Spirograph D-75; Lode NV, Groningen, The Netherlands), recording the FVC and $\mathrm{FEV}_{1}$, and evaluated by the following criteria: (1) the decrease in $\mathrm{FEV}_{1}$ of less than $10 \%$ with respect to the pre- challenge values as negative, from $10 \%$ to $20 \%$ as doubtful, and of $20 \%$ or more as positive asthmatic response; (2) the decrease in $\mathrm{FEV}_{1}$ within 2 hours after the challenge was considered to be an immediate response (IAR), that occurring between 4 and 24 hours to be a late response (LAR), and response appearing later than 24 hours after the challenge to be a delayed response (DYAR [6,7,19,20,23-25,40,43,61,76-82].

\section{Food used for the ingestion challenge}

The quantities of foods used for the food ingestion challenges were similar to those consumed usually by the patients in order to obtain the highest degree of reproducibility (Table 2). The control ingestion challenges were performed with one of the indifferent foods, such as cooked rice, cooked potatoes or $5 \%$ glucose solution according to the same schedule as those with the experimental foods $[6,7,19,20,23$ 25,75].

\section{Schedule of the food challenge}

The food ingestion challenges as well as the spirometry were performed according to the European and international standard procedures $[58,81,82]$ modified by us $[19,23,25,76-79]$ by the following schedule: (1) recording of the initial (baseline) values at 0,5 and 10 minutes; (2) ingestion of the food within 10 minutes, followed by a 1-hour waiting interval to allow the food to be ingested. During this interval the parameters were measured four times to exclude an unexpected or too early reaction; (3) recording of the post-challenge values at $0,5,10,20,30,45,60,90$ and 120 minutes, and every hour up to the $12^{\text {th }}$ hour and every second hour duringthe $22^{\text {nd }}$ and $38^{\text {th }}$ hour, the $46^{\text {th }}$ and $58^{\text {th }}$ hour interval $[19,23,25,76-79]$.

\section{Control group}

Fifteen patients suffering from perennial bronchial asthma, developing 15 late asthmatic responses (LAR) to BPT with cat or dog danders, however demonstrating negative history, skin test and RAST for the foods, volunteered to participate as controls. In these 15 patients the ingestion challenges with the most frequently consumed food, usually milk, cheese, peanuts, almonds or hazelnuts were performed according to the same schedule as applied in the patients studied.

\section{Protection tests with disodium cromoglycate administered orally}

In the 62 patients demonstrating positive asthmatic responses to the food ingestion challenge, the food ingestion challenges were repeated twice, one time after the pre-treatment with oral disodium cromoglycate (DSCG) and other time after pre-treatment with the placebo. The design of the study was double-blind, crossover, placebomatched. The basic schedule of the protection tests (pre-treated challenge) was similar to that of the non-pretreated challenge. The patients were pretreated with disodium cromoglycate and a placebo in a daily oral dose of $4 \times 200 \mathrm{mg}(=4 \times 1$ capsule), starting 2 weeks before and continuing throughout the challenge day up to 3 days after the challenge. The test was separated by an interval of 7 days. The protection tests with oral disodium cromoglycate were considered to be clinically significant when the $\mathrm{FEV}_{1}$ and/or FVC and $\mathrm{FEV}_{1}$ values recorded after the pretreated food ingestion challenge improved by at least $50 \%$ or 
more with respect to the values recorded after the non-pretreated food ingestion challenge.

\section{Statistical analysis}

Asthmatic responses were analyzed by generalized multivariate analysis of the variance (MANOVA) model [83]. The polynomials were fitted to the mean curves over time ( 8 time-points within 120 minutes and 14 time-points up to 24 hours after the challenge), and the appropriate hypotheses were tested by the modified MANOVA computerized system.

In every patient the post-challenge $\mathrm{FEV}_{1}$ values measured at each time-interval were compared with the pre-challenge values and evaluated by Wilcoxon matched-pair signed-rank test. The mean post-challenge $\mathrm{FEV}_{1}$ values were compared with corresponding postchallenge control values at each of the time-points and analyzed by the Mann-Whitney $U$ test. The results of both the protection tests (disodium cromoglycate and placebo) and their differences were statistically analyzed and evaluated by the Wilcoxon paired-signedranks test. A p value $<0.05$ was considered to be statistically significant.

\section{Results}

\section{Types of asthmatic responses}

The 62 patients developed 17 isolated immediate asthmatic responses (IAR; $\mathrm{p}<0.01$ ), 21 isolated late responses (LAR; $\mathrm{p}<0.001$ ), 8 dual late responses (DLAR, a combination of an immediate and late response; $\mathrm{p}<0.05$ ), 11 isolated delayed responses (DYAR; $\mathrm{p}<0.05)$ and 5 dual delayed asthmatic responses (DDYAR, a combination of an immediate and a delayed response; $\mathrm{p}<0.05$ ) (Tables 3-5 and Figures 1-5). The time-course of the particular asthmatic response types was as follows: IAR: onset within 80 minutes, maximum within 120 minutes and resolving within 150-180 minutes after the food ingestion; LAR: onset 4-6 hours, maximum 8-12 hours, resolving within 24-26 hours after the food ingestion; DYAR: onset 26-30 hours, maximum 32-38 hours, resolving within 56 hours after the food ingestion in most of the patients [7,19,21,23-25].

In 47 patients of the group I, in whom the food allergy participated as an additional cause, the following asthmatic response types to food ingestion challenge were registered: 14 IAR, 13 LAR, 5 DLAR, 8 DYAR and 3 DDYAR. In 15 patients of the group II, in whom the food allergy was solely cause of the asthmatic complaints, 3 IAR, 8 LAR, 3 DLAR, 3 DYAR and 2 DDYAR were observed.

\section{Control ingestion challenge}

No significant changes in the FVC and/or FEV1 values were recorded during the 62 control food ingestion challenges $(\mathrm{p}>0.1)$.

\section{Protection tests with oral disodium cromoglycate}

The protective effects of oral disodium cromoglycate as compared with the placebo were statistically highly significant for IAR $(p<0.001)$ and LAR $(\mathrm{p}<0.001)$, distinctly significant for DLAR $(\mathrm{p}<0.01)$ and significant for DYAR $(\mathrm{p}<0.05)$ and DDYAR $(\mathrm{p}<0.05)$ (Figures $1-5)$. The distribution of the protective effects of disodium cromoglycate on the particular asthmatic response types was as follows: (1) The IAR was prevented fully in 11 cases $(=65 \%)$, decreased significantly in 5 cases $(=29 \%)$ and 1 IAR case $(=6 \%)$ was not affected; (2) The 14 LAR cases were prevented fully $(=67 \%)$ and 7 cases were decreased significantly (=33\%); (3)All of the 8 DLAR cases were decreased significantly (=100\%); (4) The 1 DYAR case was prevented fully (=9\%), 9 cases were decreased significantly $(=82 \%)$ and 1 case was not affected $(=9 \%) ;(5)$ The 4 DDYAR cases were decreased significantly $(=80 \%)$, whereas 1 case remained unaffected $(=20 \%)$. No differences were observed in the protective effects of oral DSCG with respect to the individual foods $(\mathrm{p}>0.2)$.

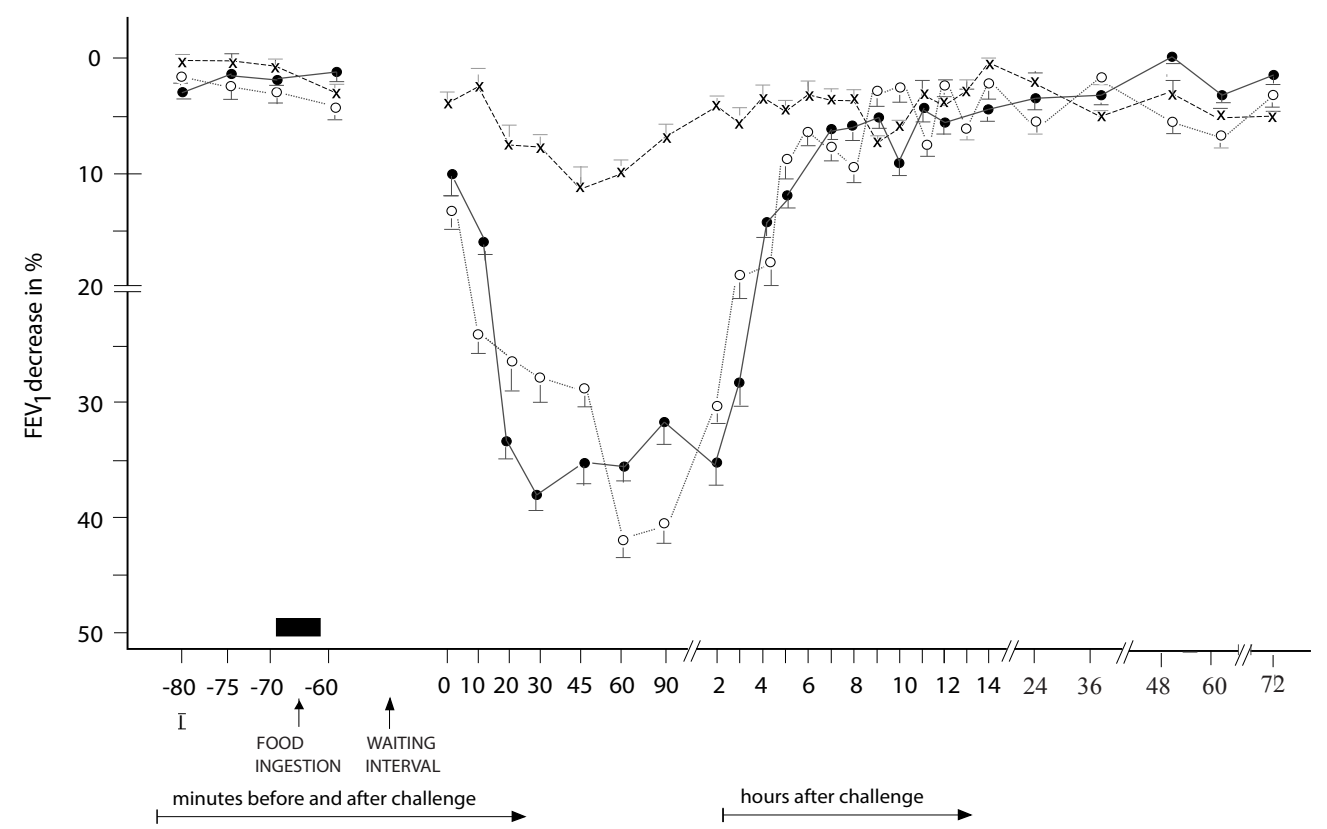

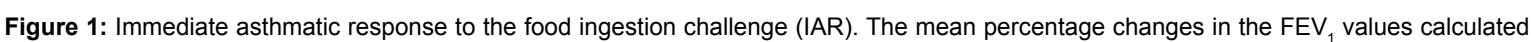
from all patients with positive IAR $(n=17)$.

$\circ=$ non-pretreated IAR; $\bullet=$ IAR pretreated with Placebo; $x=$ IAR pretreated with oral DSCG

$\mathrm{I}=$ Initial (baseline) values; Waiting interval $=1$ hour; Bars: means \pm SEM 


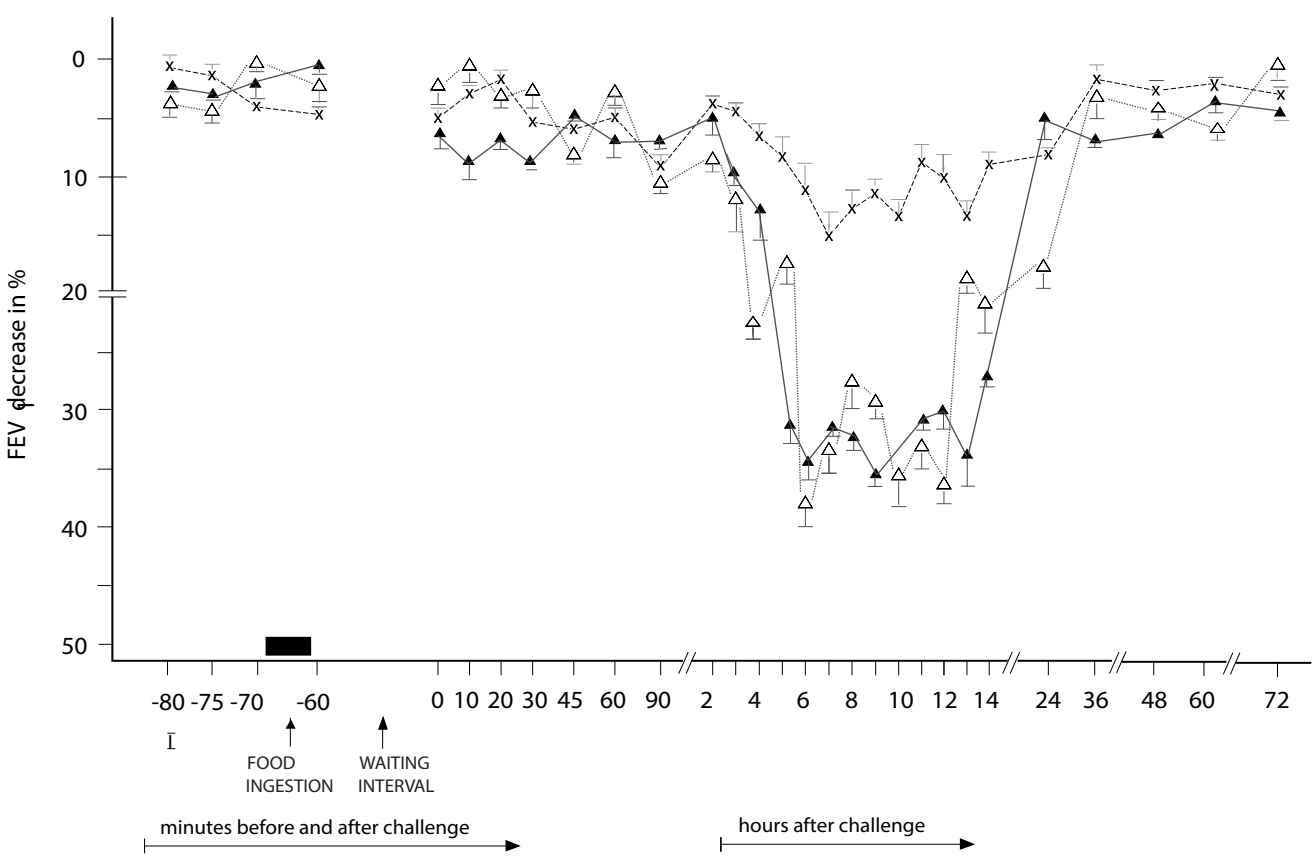

Figure 2: Late asthmatic responses to the food ingestion challenge (LAR). The mean percentage changes in the FEV values calculated from all patients with positive LAR $(n=21)$.

$\Delta=$ non-pretreatedLAR; $\Delta=L A R$ pretreated with Placebo; $x=L A R$ pretreated with oral DSCG

I=Initial (baseline) values; Waiting interval=1 hour; Bars: means \pm SEM

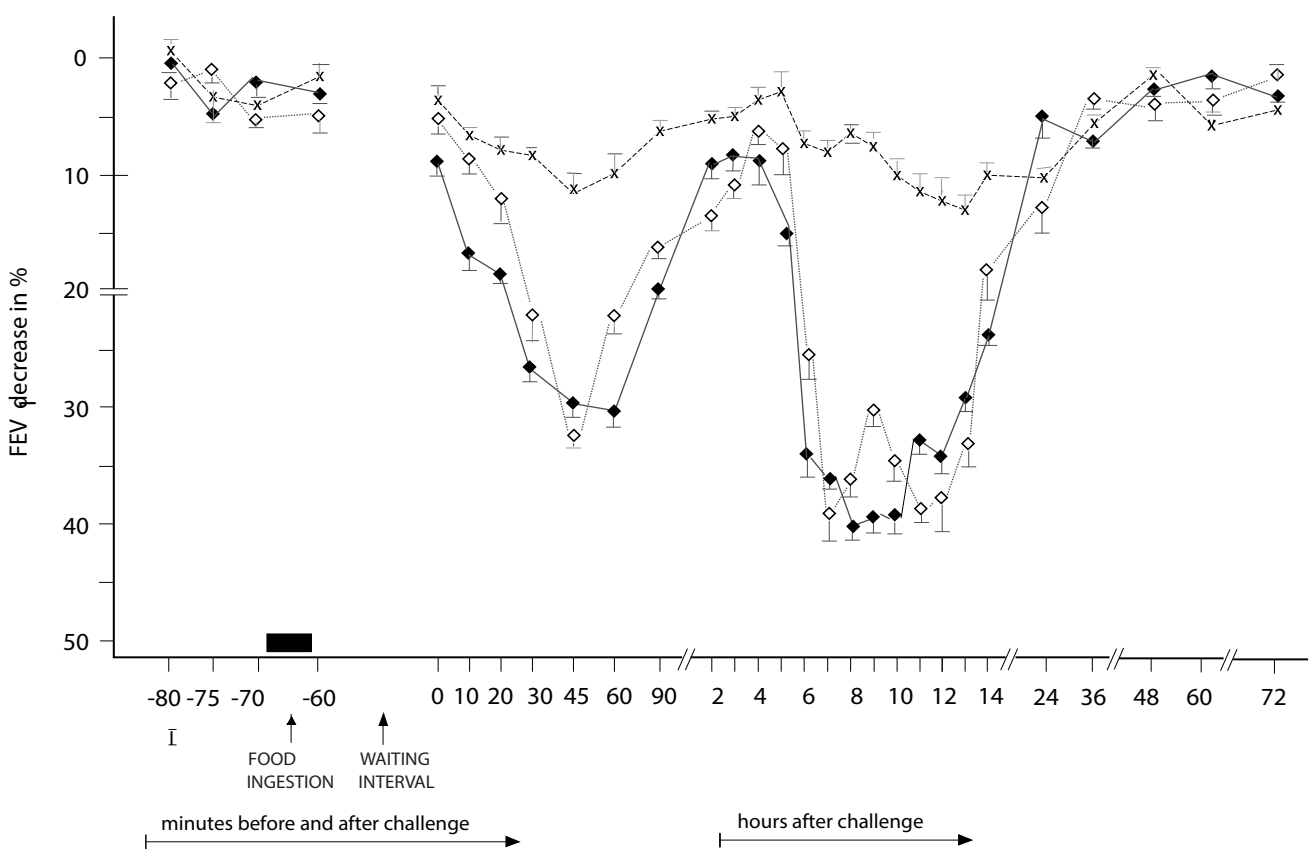

Figure 3: Dual late asthmatic response to the food ingestion challenge (DLAR). The mean percentage changes in the FEV $\mathrm{V}_{1}$ alues calculated from all patients with positive DLAR $(n=8)$.

$\diamond=$ non-pretreated DLAR; $\diamond=$ DLAR pretreated with Placebo; $x=$ DLAR pretreated with oral

I=Initial (baseline) values; Waiting interval=1 hour; Bars: means \pm SEM

\section{Protection tests with oral placebo}

The orally administered placebo did not affect any of the 62 asthmatic responses to food ingestion challenge $(p>0.2)$ and it was therefore fully ineffective.

\section{Discussion}

The causal involvement of food allergy in patients with bronchial asthma remains still underestimated and poorly understood. The participation of food allergy in bronchial asthma symptoms 


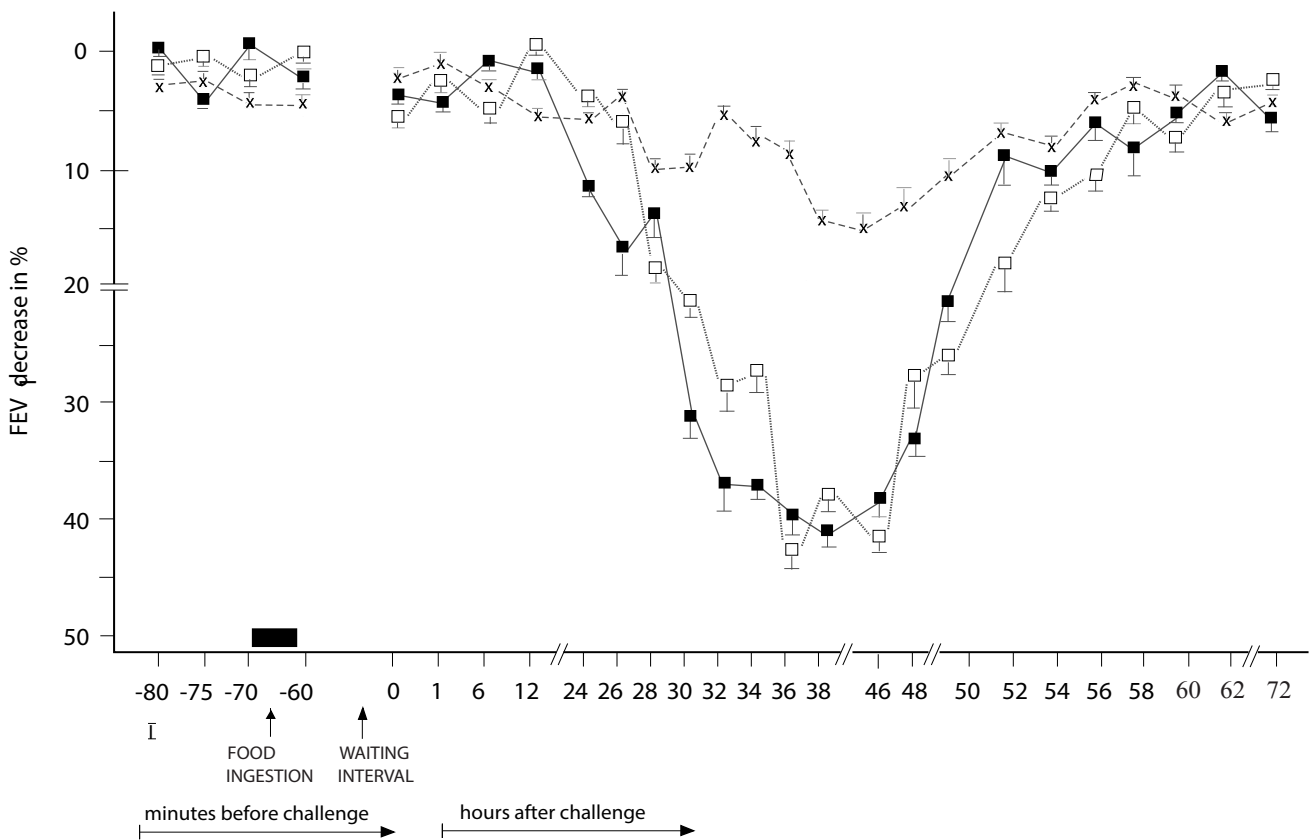

Figure 4: Delayed asthmatic response to food ingestion challenge (DYAR). The mean percentage changes in the $F_{1} \mathrm{~V}_{1}$ values calculated from all patients with positive DYAR $(n=11)$

$\square=$ non-pretreated DYAR; $₫=$ DYAR pretreated with Placebo; $x=$ DYAR pretreated with oral DSCG

I=Initial (baseline) values; Waiting interval=1 hour; Bars: means \pm SEM

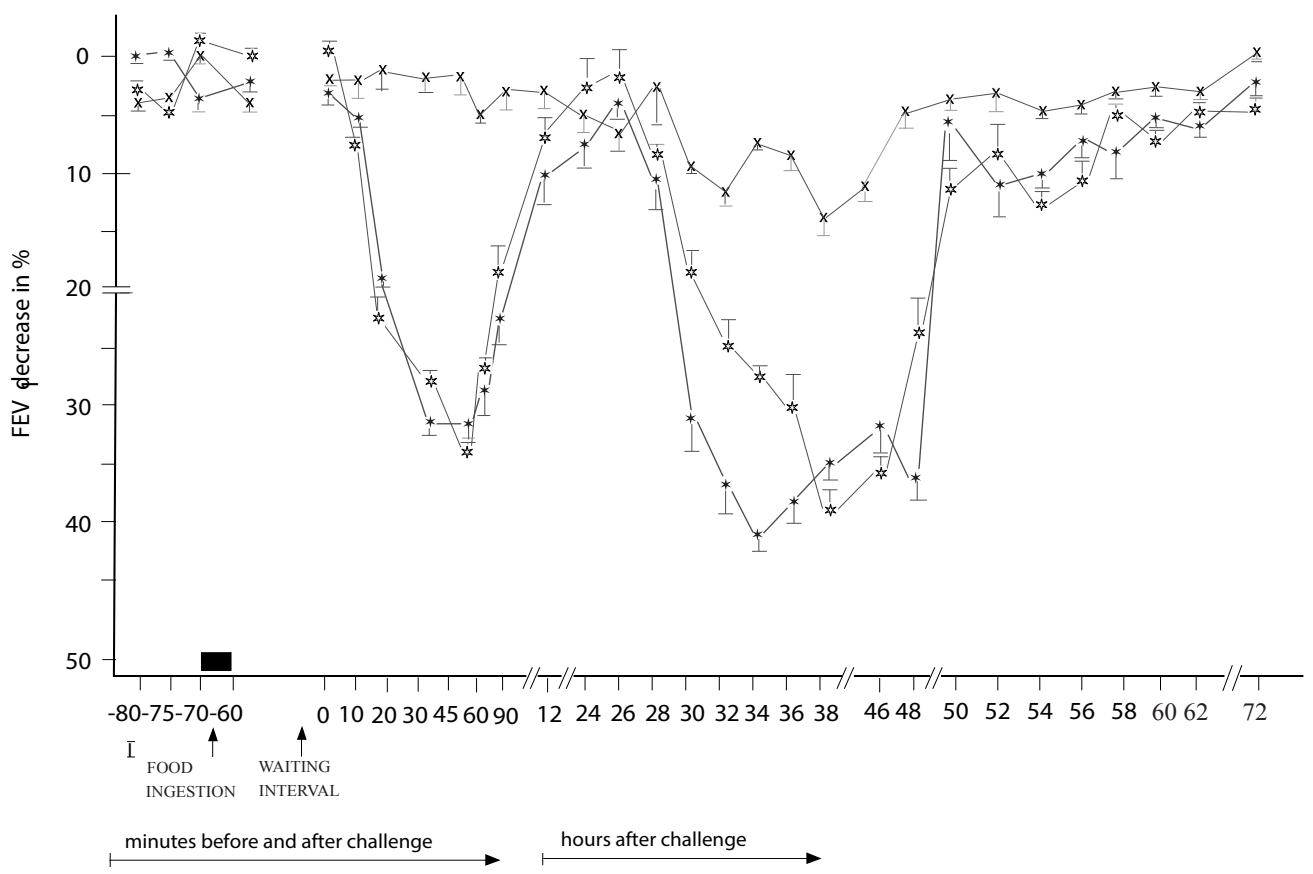

Figure 5: Dual delayed asthmatic response to food ingestion challenge (DDYAR). The means percentage changes in the FEV values calculated from all patients with positive DDYAR $(n=5)$.

\#==non-pretreated DDYAR; *=DDYAR pretreated with Placebo; $x=$ DDYAR pretreated with oral DSCG

I = Initial (baseline) values; Waiting interval=1 hour; Bars: means \pm SEM

has already been discussed in the literature, sometimes from controversial points of view [1-5,7,12-17,19,21,23-25-27,37-42, $45,48,49,52,53,62,66,68,70,71,84-88]$. There is still a dearth of information concerning the well-documented data conforming the causative role of foods and food allergy in asthmatic complaints. The diagnostic confirmation of the role of foods and food allergy in the clinical manifestations is performed in the practice by means of disease history, skin tests and/or determination of the food-specific IgE antibody in the serum. However, these tests demonstrate variable degree of correlation with the clinical manifestation of bronchial asthma and their predictor 
value does not seem to be fully satisfactory $[1-8,11,12,14,15,19-21,23$ $25,27,28,31,38-39,41,45,48-53,55-57,60,61,80,81]$. The involvement of the food allergy in in the bronchial asthma, can only be confirmed by means of the food ingestion challenge, demonstrating particular types of asthmatic response induced by certain food(s), which can be recorded quantitatively by means of objective functional parameters, such as lung function, in their dynamic course $[2,7,8,10,11,14,15,19$, 21,23-25,38,39,40,44-51,53-61,63, 64,84-88].

The five types of asthmatic response induced by food ingestion challenge in bronchial asthma patients, described in this as well as in our previous papers $[7,19,23-25,84]$, may be comparable with the basic types of the asthmatic response to the bronchial challenge with inhalant allergens [76-79].

The exact hypersensitivity mechanisms underlying the particular types of asthmatic response to food ingestion challenge are not yet fully clarified and need more concurrent immunologic and clinical studies. The IAR due to the IgE-mediated food allergy has been most extensively investigated [1-3.5.7-12,14-17,21-23,25,27,37,38,40,41,45,53,67]. The LAR to food allergy has also been reported, however, the underlying immunologic mechanism has not been satisfactorily clarified $[7,16,19,21,23,26-28,37,66,89,90]$. Some investigators suggested a possible participation of immune-complexes, whereas others presumed involvement of IgE antibodies and/or various modifications of the IgEmediated hypersensitivity mechanisms. In the DYAR to food ingestion challenge, described already by usin the past $[7,19,23,84]$, which is analogical to the DYAR induced by inhalant allergens $[78,79]$ the involvement of the cell-mediated hypersensitivity mechanism(s) could be presumed. Nevertheless, there is still a great dearth of structural information and research data concerning the exact role and the mode of involvement of immunological mechanisms in the particular types of the food-induced asthmatic response in large group of well-defined and diagnosed patients with bronchial asthma. The protective effects of oral disodium cromoglycate on various clinical manifestations due to the adverse reactions to foods, among which to food allergy, have regularly been studied and reported in the literature [1-7,15,24,65,6774]. However, in most of these studies, the protective effects of this drug on the skin disorders, such as atopic eczema, dermatitis, urticaria, colon disorders, such as colitis ulcerosa, Crohn's disease, oesophagitis or multiple symptoms due to the adverse reactions to foods have been investigated. Moreover, in most of these studies, the protective effects of disodium cromoglycate were evaluated predominantly by recording of subjective parameters, such as symptom scores. Unfortunately, the protective effects of disodium cromoglycate were not related to the qualitatively and quantitatively well-defined stimulus, such as ingestion challenge with a certain food(s). Nevertheless, data illustrating the possible protective effects of oral disodium cromoglycate on the asthmatic response types induced by food allergy, in a large group of well-defined patients with bronchial asthma, are not available until yet.

Disodium cromoglycate (Cromolyn, DSCG) is a disodium salt of 1, 3-bis-(2-carboxychromone-5-yloxy)-2-hydroxypropane. Disodium cromoglycate administered orally in a daily dose of $4 \times 200$ $\mathrm{mg}$ has demonstrated statistically significant protective effects on all 5 types of asthmatic response to food ingestion challenge, however, with some differences and variations [91-95]. The differences in the protective effects of the oral DSCG could partly be explained by the manifold pharmacologic and biochemical effects of this drug, which can be summarized as follows: (1) Protection of mast cells and basophils from their degranulation and subsequent release of various mediators and constituents; (2) Stabilization of the cell membranes by blocking calcium transport, inhibition of calcium gate openings induced by antigen and ) Elevation of the membrane-associated cyclic adenosine monophosphate (cAMP); (3) Inhibition and decrease of the neutrophil mobility and chemotactic activity; (4) Increase of the cAMP and decrease cGMP in neutrophils, thrombocytes and lung tissue cells; (5) Inhibition of action of protein kinase C, an enzyme that requires calcium phosphatidylserine for the full expression of its activity; (6) Reduction of a number of complement reactions, such as $\mathrm{C} 3 \mathrm{~b}$ and immunoglobulin $\mathrm{G}(\mathrm{IgG})$ rosettes $(\mathrm{Fc} \gamma)$ on human eosinophils; (7) Inhibition of TNFa release from human lung, intestinal and peritoneal mast cells; (8) Inhibition of production of TNF- $\alpha$ and IL-5 by human lung specimens; (9) Inhibition ofIgE-dependent enzyme production and release of neutrophil chemotactic factor from human alveolar macrophages; (10) Reduction of numbers of human eosinophils, neutrophils, T-lymphocytes and tissue macrophages; (11) Decrease of the expression of ICAM-1, VCAM-1 and ELAM-1 of in biopsies of the bronchial mucosa and on the epithelial cells; (12) Inhibition of the influx of neutrophils and release of TNFa and IL-6 into BAL fluid following allergen challenge; (13) Inhibition of release of prostaglandin $\mathrm{D}_{2}$ and leukotriene $\mathrm{C}_{4}$ from dispersed lung cell and suppression of leukotriene $\mathrm{C}_{4}$ synthesis by inhibition of mRNA expression of $\mathrm{LTC}_{4}$ synthase; (14) Suppression of antibody-dependent cytotoxicity of human neutrophils and eosinophils, and the anti-IgG - induced degranulation of human basophils; (15) Increase the survival time of human platelets and reduction the IgE-dependent monoamine uptake in platelets; (16) Inhibition of IgE isotype switching and enhancement of $\mathrm{IgG}_{4}$ production; (17) Inhibition of cell adhesion and immigration of neutrophils, their recruitment onto vascular endothelium via Annexin-A1 mobilization, as well as the myeloperoxidase release from these cells; (18) Decrease of production of eosinophilic cationic protein; (19) Decrease of amounts of leukotriene $B_{4}$ and $C_{4}$ in blood, BAL fluid and tears; (20) Inhibition of plasma extravasation and airway neurogenic inflammation, presumably through functional antagonism of tachykinins; (21) Inhibition of assembly of an active NADPH oxidas (nicotinamide adenine dinucleotide phosphate or triphosphopyridine nucleotide) in neutrophils and prevention of oxygen radical-induced tissue damage; (22) Prevention of the G-protein activation; (23) Inhibition of protein kinase C (PKC) activity; (24) Inhibition of proliferative responses of $\mathrm{T}$ - and $\mathrm{B}$-cell subsets stimulated with mitogens together with recombinant IL-2(rIL-2); (25) Inhibition of absorption of the major soybean allergen, Gly $\mathrm{m}$ Bd30K in human intestinal Caco-2 cells via clathrin- and/or caveolae-dependent endocytosis.

On the other hand, there is a lack of structural knowledge of the processes in the gastro-intestinal tract through which the foods and their parts act as an antigen and initiate the hypersensitivity reactions leading to the certain type of response of the certain organ [3,5$9,13,16,17,19-37,80]$. The most important questions of this poorly understood area of clinical allergology concern the role of the intestine in controlling and monitoring the uptake of ingested foods and their antigens, the mechanisms involved directly as well as indirectly during the resorption of the potential antigens, presentation of the food antigens and their components by which types of APC cells to which kinds of target cells, which type of cells are activated and involved in the further steps of this immunologic process, the mode of antigen transport from the gut to other organs and tissues, e.g. bronchial tree and lastly the whole complex of factors determining the target and response-organ as well as the type of the organ response [3,5$913,16,17,19-37,80]$.

There are several hypotheses attempting to explain the the 
Citation: Pelikan Z (2014) Protective Effects of Oral Disodium Cromoglycate on the Asthmatic Responses Induced by Food Allergy. J Allergy Ther 5: 163. doi: $10.4172 / 2155-6121.1000163$

mechanisms through which the foods participate in hypersensitivity states. One of the most interesting and promising theories concerns the mucosal barrier and its role in handling of (food) antigen by the gut (gastro-intestinal tract) [6,7-9,19,21,22,28-37]. The involvement of the particular hypersensitivity mechanisms in the individual types of the organ response, e.g. asthmatic response, to ingested food is not yet fully clarified. However, there is evidence that besides the type I (immediate) hypersensitivity, also the type III (late, immune-complex-mediated) and the type IV (delayed, cell-mediated) hypersensitivity may be involved in the pathogenesis of the food allergy [1-9,16,19-36,59].

Regarding the results of this study, of our previous studies $[7,19,23,25,84]$ and the other investigators results $[9,13,21,22,26-35]$ the involvement of the immediate hypersensitivity mechanism (Type I) in the IAR, the late hypersensitivity mechanisms (Type III) in the LAR and the delayed hypersensitivity (cell-mediated, Type IV) in the DYAR to the food ingested, at least in some of their modifications, cannot be excluded in the patients with bronchial asthma demonstrating positive asthmatic responses to food ingested. Despite a dearth of exact knowledge of the (hypersensitivity) mechanisms underlying the basic types of asthmatic response to foods ingested as well as the exact mode of pharmacologic action of oral DSCG, it can be concluded, that the disodium cromoglycate in a daily oral dose of $4 \times 200 \mathrm{mg}$ significantly prevented all 5 basic types of asthmatic response to food ingestion challenge. Oral DSCG seems therefore to be a suitable drug for the prophylaxis and control of asthmatic complaints due to the ingested foods acting most probably through the food allergy mechanism(s). If necessary, the oral DSCG can be combined with other additional pharmacologic agents to improve the control of asthmatic complaints.

\section{References}

1. Sampson HA Burks AW (2009) Adverse reactions to foods. In: Adkinson NF, Bochner BS, Busse WW, Holgate ST, Lemanske RF,Simons FE, Eds. Middleton's Allergy-Principles \& Practice (7thedn) Philadelphia/PA: MosbyElsevier Inc: 1139-1167.

2. Ayres JG, Baker JC (2002) Food-induced asthma. In: Brostoff J, Challacombe SJ, Eds. Food allergy and intolerance (2ndedn) London, Edinburgh, New York, Philadelphia, St. Louis, Sydney, Toronto: Saunders/Elsevier Ltd: 529-540.

3. Sicherer SH1, Sampson HA (2010) Food allergy. J Allergy Clin Immunol 125: S116-125.

4. Bock SA (2003) Diagnostic evaluation. Pediatrics 111: 1638-1644

5. Sampson HA (2004) Update on food allergy. J Allergy Clin Immunol 113: 805819.

6. Pelikan Z (2002) Rhinitis, secretory otitis media and sinus disease caused by food allergy. In: Brostoff J, Challacombe SJ, Eds. Food allergy and intolerance (2ndedn) London, Edinburgh, New York, Philadelphia, St. Louis, Sydney, Toronto : Saunders/Elsevier Ltd: 499-528.

7. Pelikan Z, Pelikan-Filipek M, Food allergy (1991) I. Definition, other adverse reactions to foods, the mucosal gastro-intestinal barrier. II. Non-optimal function of the mucosal gastro-intestinal barrier; types of allergic reaction; symptoms, diagnostic procedure and treatment. Dutch $\mathrm{J}$ of Medicine (Ned Tijdschr Geneesk) 135: 49-55.

8. Wray D (2002) Oral manifestations of food allergy and intolerance. In: Brostoff J, Challacombe SJ, Eds. Food allergy and intolerance. (2ndedn). London, Edinburgh, New York, Philadelphia, St. Louis, Sydney, Toronto: Saunders/ Elsevier Ltd: 561-570.

9. Berin MC, Sampson HA (2005) Food allergy. Immunophysiology. In: Mestecky J, Binnenstock J, Lamm M, Strober W, McGhee JR, Mayer L (eds). Mucosal immunology (3rdedn). Burlington (MA,USA), San Diego (CA,USA), London : Elsevier-Academic Press: 1335-1350.

10. Wood RA (2009) Oral food challenge testing. In: Adkinson NF, Bochner BS Busse WW, Holgate ST, Lemanske RF, Simons FE, Eds. Middleton's AllergyPrinciples \& Practice (7thedn) Philadelphia/PA: Mosby-Elsevier Inc: 1309-1317.
11. Bock SA (1997) In vivo diagnosis: skin testing and oral challenge procedures In: Metcalfe DD, Sampson HA, Simon RA (Eds). Food allergy: Adverse reactions to foods and food additives (2ndedn) Oxford (UK), Cambridge (MA/ USA), London, Edinburgh, Carlton (Victoria, Australia), Paris, Berlin, Vienna: Blackwell Sci: 151-166

12. James JM (2003) Respiratory manifestations of food allergy. Pediatrics 111 1625-1630.

13. Jyonouchi H (2008) Non-IgE mediated food allergy. Inflamm Allergy Drug Targets 7: 173-180.

14. Burks AW, Tang M, Sicherer S, Muraro A, Eigenmann PA, et al. (2012) ICON: food allergy. J Allergy Clin Immunol 129: 906-920.

15. Boyce JA, Assa'ad A, Burks AW, Jones SM, Sampson HA, et al. (2010) Guiderlines for the diagnosis and management of food allergy in the United States: Report of the NIAID-sponsored expert panel. J Allergy Clin Immunol 126: S1-S58.

16. Vickery BP, Chin S, Burks AW (2011) Pathophysiology of food allergy. Pediatr Clin North Am 58: 363-376, ix-x.

17. Mansoor DK, Sharma HP (2011) Clinical presentations of food allergy. Pediatr Clin North Am 58: 315-326, ix.

18. Björnsson E, Janson C, Plaschke P, Norrman E, Sjöberg O (1996) Prevalence of sensitization to food allergens in adult Swedes. Ann Allergy Asthma Immunol 77: 327-332.

19. Pelikan Z, Pelikan-Filipek M (1987) Bronchial response to the food ingestion challenge. Ann Allergy 58: 164-172.

20. Pelikan Z (1988) Nasal response to food ingestion challenge. Arch Otolaryngol Head Neck Surg 114: 525-530.

21. Novembre E, de Martino M, Vierucci $A$ (1988) Foods and respiratory allergy. J Allergy Clin Immunol 81: 1059-1065.

22. Fickling WE, Robertson DAF (2002) Immunologically mediated damage of the gut. In: Brostoff J, Challacombe SJ, Eds. Food allergy and intolerance. 2nd Ed. London, Edinburgh, New York, Philadelphia, St. Louis, Sydney, Toronto : Saunders/ Elsevier Ltd, 293-301.

23. Miesen WMAJ, Pelikan-Filipek M, Oers $\vee J A H$, Pelikan DMV, Trimbach YA et al. (1997) Basic types of the asthmatic response to the food ingestion challenge. J Allergy Clin Immunol, 99 (No 1, Part 2): S150 (Abstract No 606).

24. Pelikan Z (1996) The late nasal response, its clinical and immunologic features, possible mechanisms and pharmacologic modulation. Thesis. Amsterdam: Free University of Amsterdam

25. Pelikan Z (2002) Asthmatic response (AR) to the food ingestion challenge: a comparison of the double-blind placebo-controlled (DBPCC) and open placebo controlled (OPCC) challenges. Allergy 57 (Suppl. 73): 86 (Abstr.238).

26. Paganelli R, Levisky RJ, Atherton DJ (1981) Detection of specific antigen within circulating immune complexes; validation of the assay and its application to food antigen-antibody complexes formed in healthy and food-allergic subjects. Clin Exp Immunol 46: 44-53.

27. Sabra A, Bellanti JA, Rais JM, Castro HJ, de Inocencio JM, et al. (2003) IgE and non-lgE food allergy. Ann Allergy Asthma Immunol 90: 71-76.

28. Bellanti JA1, Zeligs BJ, Malka-Rais J, Sabra A (2003) Abnormalities of Th1 function in non-lgE food allergy, celiac disease, and ileal lymphonodular hyperplasia: a new relationship? Ann Allergy Asthma Immunol 90: 84-89.

29. Pérez-Machado MA, Ashwood P, Torrente F, Salvestrini C, Sim R, et al. (2004) Spontaneous $\mathrm{T}(\mathrm{H}) 1$ cytokine production by intraepithelial but not circulating $T$ cells in infants with or without food allergies. Allergy 59: 346-353.

30. Paajanen L, Vaarala O, Karttunen R, Tuure T, Korpela R, et al. (2005) Increased IFN-gamma secretion from duodenal biopsy samples in delayed-type cow's milk allergy. Pediatr Allergy Immunol 16: 439-444.

31. Scott-Taylor TH, Hourihane JOB, Strobel S (2010) Correlation of allergenspecific IgG subclass antibodies and $\mathrm{T}$ lymphocyte cytokine responses in children with multiple food allergies. Pediatr Allergy Immunol 21: 935-944.

32. Veres G, Westerholm-Ormio M, Kokkonen J, Arato A, Savilahti E (2003) Cytokines and adhesion molecules in duodenal mucosa of children with delayed-type food allergy. J Pediatr Gastroenterol Nutr 37: 27-34.

33. Hauer AC, Breese EJ, Walker-Smith JA, MacDonald TT (1997) The frequency 
Citation: Pelikan Z (2014) Protective Effects of Oral Disodium Cromoglycate on the Asthmatic Responses Induced by Food Allergy. J Allergy Ther 5: 163. doi: $10.4172 / 2155-6121.1000163$

Page 10 of 11

of cells secreting interferon-gamma and interleukin- $4,-5$, and -10 in the blood and duodenal mucosa of children with cow's milk hypersensitivity. Pediatr Res 42: 629-638.

34. Chuang SL, Hayes PJ, Ogundipe E, Haddad M, MacDonald TT, et al. (2009) Cow's milk protein-specific T-helper type I/II cytokine responses in infants with necrotizing enterocolitis. Pediatr Allergy Immunol 20: 45-52.

35. Osterlund $P$, Suomalainen $H$ (2002) Low frequency of CD4+, but not CD8+, $T$ cells expressing interferon-gamma is related to cow's milk allergy in infancy. Pediatr Allergy Immunol 13: 262-268.

36. Youngman KR, Lazarus NH, Butcher EC (2005) Lymphocyte homing: Chemokines and adhesion molecules in T cell and IgA plasma cell localization in the mucosal immune system (2005) In: Mestecky J, Binnenstock J, Lamm M, Strober W, McGhee JR, Mayer L (eds). Mucosal immunology (3rd). Burlington (MA,USA), San Diego (CA,USA), London : Elsevier-Academic Press 667-680.

37. Ford RP, Hill DJ, Hosking CS (1983) Cows' milk hypersensitivity: immediate and delayed onset clinical patterns. Arch Dis Child 58: 856-862.

38. James JM, Bernhisel-Broadbent J, Sampson HA (1994) Respiratory reactions provoked by double-blind food challenges in children. Am J Respir Crit Care Med 149: 59-64

39. James JM, Eigenmann PA, Eggleston PA, Sampson HA (1996) Airway reactivity changes in asthmatic patients undergoing blinded food challenges. Am J Respir Crit Care Med 153: 597-603.

40. Arai Y, Sano Y, Ito K, Iwasaki E, Mukouyama T, et al. (1998) [Food and food additives hypersensitivity in adult asthmatics. I. Skin scratch test with food allergens and food challenge in adult asthmatics]. Arerugi 47: 658-666.

41. Bousquet J, Chañez P, Michel FB (1997) The respiratory tract and food hypersensitivity. In: Metcalfe DD, Sampson HA, Simon RA, eds. Food allergy: Adverse reaction to foods and food additives. 2nd Ed. Cambridge (MS/USA): Blackwell Sci Publ, Inc 235-244.

42. Bird JA, Burks AW (2009) Food allergy and asthma. Prim Care Respir J 18 258-265.

43. Pelikan Z (1998) The role of allergy in sinus disease. Children and adults. Clin Rev Allergy Immunol 16: 55-156.

44. Mankad VS, Williams LW, Lee LA, LaBelle GS, Anstrom KJ, et al. (2008) Safety of open food challenges in the office setting. Ann Allergy Asthma Immunol 100 469-474.

45. Niggemann B, Beyer K (2007) Pitfalls in double-blind, placebo-controlled ora food challenges. Allergy 62: 729-732.

46. Lieberman J, Sampson HA (2010) Outpatient, open oral food challenges- a one year reprospective study. Ann Allergy Asthma \& Immunol 105 (Suppl 1): A 15 (Abstr 46).

47. Lieberman JA, Huang FR, Sampson HA, Nowak-WÄ ${ }^{T M}$ grzyn A (2012) Outcomes of 100 consecutive open, baked-egg oral food challenges in the allergy office. J Allergy Clin Immunol 129: 1682-1684.

48. Asero R, Fernandez-Rivas M, Knulst AC, Bruijnzeel-Koomen CA (2009) Double-blind, placebo-controlled food challenge in adults in everyday clinical practice: a reappraisal of their limitations and real indications. Curr Opin Allergy Clin Immunol 9: 379-385.

49. Bindslev-Jensen C, Ballmer-Weber BK, Bengtsson U, Blanco C, Ebner C, et al. (2004) Standardization of food challenges in patients with immediate reactions to foods--position paper from the European Academy of Allergology and Clinical Immunology. Allergy 59: 690-697.

50. Sicherer SH (1999) Food allergy: when and how to perform oral food challenges Pediatr Allergy Immunol 10: 226-234.

51. Bahna SL (2003) Diagnosis of food allergy. Ann Allergy Asthma Immunol 90 $77-80$

52. Lee J, Garrett JP, Brown-Whitehorn T, Spergel JM (2013) Biphasic reactions in children undergoing oral food challenges. Allergy Asthma Proc 34: 220-226.

53. Fiocchi A, Schünemann HJ, Brozek J, Restani P, Beyer K, et al. (2010) Diagnosis and Rationale for Action Against Cow's Milk Allergy (DRACMA): a summary report. J Allergy Clin Immunol 126: 1119-1128.

54. Venter C, Pereira B, Voigt K, Grundy J, Clayton CB, et al. (2007) Comparison of open and double-blind placebo-controlled food challenges in diagnosis of food hypersensitivity amongst children. J Hum Nutr Diet 20: 565-579.
55. Baker H, Luyt D, Stern M (1999) Open challenge to nuts in children. Allergy 54: 79-80.

56. Bock SA, Sampson HA, Atkins FM, Zeiger RS, Lehrer S, et al. (1988) Doubleblind, placebo-controlled food challenge (DBPCFC) as an office procedure: a manual. J Allergy Clin Immunol 82: 986-997.

57. Nowak-Wegrzyn A, Assa'ad AH, Bahna SL, Bock SA, Sicherer SH, et al. (2009) Work Group report: oral food challenge testing. J Allergy Clin Immunol 123 S365-383.

58. Vlieg-Boerstra BJ, van der Heide S, Bijleveld CM, Kukler J, Duiverman EJ, et al. (2007) Placebo reactions in double-blind, placebo-controlled food challenges in children. Allergy 62: 905-912.

59. Noma T, Yoshizawa I, Aoki K, Sugawara Y, Odajima H, et al. (1998) Correlation between antigen-specific IL-2 response test and provocation test for egg allergy in atopic dermatitis. Clin Exp Allergy 28: 1120-1130.

60. Williams LW (2001) Skin testing and food challenges for the evaluation of food allergy. Curr Allergy Rep 1: 61-66.

61. Sicherer SH, Morrow EH, Sampson HA (2000) Dose-response in double-blind placebo-controlled oral food challenges in children with atopic dermatitis. $J$ Allergy Clin Immunol 105: 582-586.

62. Melillo G, Bonini S, Cocco G, Davies RJ, Monchy de JGR, et al. (1997) Provocation tests with allergens Allergy 52 (Suppl 35): 5-36.

63. Roberts G, Lack G (2003) Food allergy and asthma--what is the link? Paediatr Respir Rev 4: 205-212.

64. Yum HY, Yang HJ, Kim KW, Song TW, Kim WK, et al. (2011) Oral food challenges in children. Korean J Pediatr 54: 6-10.

65. Correa FF, Vieira MC, Yamamoto DR, Speridião Pda G, de Morais MB (2010) Open challenge for the diagnosis of cow's milk protein allergy. J Pediatr (Rio J) $86: 163-166$

66. Dahl R (1978) Disodium cromoglycate and food allergy. The effect of oral and inhaled disodium cromoglycate in a food allergic patient. Allergy 33: 120-124.

67. Wang J, Liu AH (2011) Food allergies and asthma. Curr Opin Allergy Clin Immunol 11: 249-254.

68. Youlten LJF (2002) Drug treatment of food allergy and intolerance. In: Brostoff $\mathrm{J}$, Challacombe SJ, Eds. Food allergy and intolerance (2nd Ed). London, Edinburgh, New York, Philadelphia, St. Louis, Sydney, Toronto : Saunders/ Elsevier Ltd, 921-926.

69. Harries MG, O'Brien IM, Burge PS, Pepys J (1978) Effects of orally administered sodium cromoglycate in asthma and urticaria due to foods. Clin Allergy 8: 423 427.

70. Ortolani C, Pastorello E, Zanussi C (1983) Prophylaxis of adverse reactions to foods. A double-blind study of oral sodium cromoglycate for the prophylaxis of adverse reactions to foods and additives. Ann Allergy 50: 105-109.

71. Smith LJ, Muñoz-Furlong A (2002) The management of food allergy. In Metcalfe DD, Sampson HA, Simon RA, eds. Food allergy. Adverse reaction to foods and food additives. 2nd Ed. Cambridge (MS/USA): Blackwell Sci Publ, Inc 235-244.

72. Ellul-Micallef R (1983) Effect of oral sodium cromoglycate and ketotifen in fishinduced bronchial asthma. Thorax 38: 527-530.

73. Dahl R, Zetterström (1978) The effect of orally administered sodium cromoglycate on allergic reactions caused by food allergens. Clin Allergy 8 : 419-422.

74. Edwards AM (1995) Oral sodium cromoglycate: its use in the management of food allergy. Clin Exp Allergy 25 Suppl 1: 31-33.

75. Esteban MM, Ojeda JA, Laso MT, Pascual C (1977) Oral sodium cromoglycate in food allergy. Acta Allergol Suppl 13: 102-108.

76. Pelikan Z, Pelikan-Filipek M (1989) Effects of oral cromolyn on the nasa response due to foods. Arch Otolaryngol Head Neck Surg 115: 1238-1243.

77. Pelikan Z, Pelikan M, Kruis M, Berger MP (1986) The immediate asthmatic response to allergen challenge. Ann Allergy 56: 252-260.

78. Pelikan Z, Pelikan-Filipek M (1986) The late asthmatic response to allergen challenge-Part I+II. Ann Allergy 56 : 414-420, 421-435. 
Citation: Pelikan Z (2014) Protective Effects of Oral Disodium Cromoglycate on the Asthmatic Responses Induced by Food Allergy. J Allergy Ther 5: 163. doi: $10.4172 / 2155-6121.1000163$

Page 11 of 11

79. Pelikan Z (2010) Delayed-type asthmatic response to bronchial challenge with allergen, I: clinical features. Ann Allergy Asthma Immunol 104: 394-404.

80. Pelikan Z (2011) Delayed asthmatic response: a new phenotype of bronchial response to allergen challenge and soluble adhesion molecules in the serum. Ann Allergy Asthma Immunol 106: 119-130.

81. Bousquet J, Michel FB, In vivo methods for study of allergy; skin tests, techniques and interpretation (1993) In: Middleton E.Jr, Reed ChE, Ellis EF, Adkinson NF, Yunginger JW, Busse WW, Eds. Allergy, principles \& practice (4 th Ed). St.Louis, Baltimore, Boston, Chicago, London, Philadelphia, Portland, Sydney, Toronto: Mosby-Year Book, Inc, 573-594.

82. Sterk PJ, Fabbri LM, Quanjer PH, Cockcroft DW, O’Byrne PM, et al. (1993) Airway responsiveness. Standardized challenge testing with pharmacological, physical and sensitizing stimuli in adults. Report Working Party Standardization of Lung Function Tests, European Community for Steel and Coal. Official Statement of the European Respiratory Society. Eur Respir J Suppl 16: 53-83.

83. Postma DS, Boezen HM (2004) Rationale for the Dutch hypothesis. Allergy and airway hyperresponsiveness as genetic factors and their interaction with environment in the development of asthma and COPD. Chest 126: 96S-104S.

84. Pelikan Z (2013) Asthmatic response to milk ingestion challenge in adults: a comparison of the open and double-blind challenges. Int Arch Allergy Immunol 161: 163-173.

85. Hughes JL, Brown T, Edgar JD, Shields MD (2010) Peanut allergy and allergic airways inflammation. Pediatr Allergy Immunol 21: 1107-1113.

86. Spergel JM, Sharma HP (2014) Clinical manifestations of food allergy. In: Sicherer SH (Ed). Food allergy-Practical diagnosis and management. Boca Raton (FL/USA): CRC Press (Taylor \& Francis Group) 1-20.

87. Noone S Assa'ad AH (2014) The oral food challenge procedure. In: Sicherer
$\mathrm{SH}(\mathrm{Ed})$. Food allergy-Practical diagnosis and management. Boca Raton (FL/ USA): CRC Press (Taylor \& Francis Group) 151-164.

88. James JM (2014) Respiratory conditions associated with food allergy. In: Sicherer SH (Ed). Food allergy-Practical diagnosis and management. Boca Raton (FL/USA): CRC Press (Taylor \& Francis Group) 110-128.

89. Bentley AM, Kay AB, Durham SR (1997) Human late asthmatic responses: In: Kay AB (ed). Allergy and Allergic Diseases. Oxford (UK): Blackwell Sci Ltd; 1113-1129).

90. Christodoulopoulos P, Tulic MK, Kontolemas M, Hamid Q (2003) Immunopathology of allergic airway inflammation. In: Adkinson NF, Yunginger JW, Busse WW, Bochner BS, Holgate ST, Simons FER, Editors. Middletons's Allergy, Principles \& Practice. 6th Ed. St. Louis/MO: Mosby Inc; 501-514.

91. Pelikan Z (1999) Anti-allergic drugs and immunotherapy In: Principles of Immunopharmacology. Nijkamp FP, Parnham MJ (Eds). Birkhäuser Verlag, Basel, Boston, Berlin, 243-268.

92. Foreman JC, Pearce FL (1993) Cromolyn and nedocromil. In: Middleton E, Reed ChE, Ellis EF, Adkinson NF, Younginger JW,Busse WW (eds). Allergy, Principles \& Practice. 4th Ed. St. Louis/MO: Mosby-Year Books, Inc; 926-940.

93. Brogden RN, Speight TM, Avery GS (1974) Sodium cromoglycate (cromolyn sodium): a review of its mode of action, pharmacology, therapeutic efficacy and use. Drugs 7: 164-282.

94. Eady RP, Norris AA (1997) Nedocromil sodium and sodium cromoglycate: Pharmacology and putative modes of action. In: Kay AB (Ed). Allergy and Allergic Diseases. Oxford (UK): Blackwell Sci Publ: 584-595.

95. Norris AA (1996) Pharmacology of sodium cromoglycate. Clin Exp Allergy 26 Suppl 4: 5-7.

This article was originally published in a special issue, Food Allergy handled

by Editor. Dr. Glover Sarah Camille, University of Florida, USA. 